\title{
PERAN PENGETAHUAN AWAL TENTANG ANAK BERKEBUTUHAN KHUSUS DAN EFIKASI GURU TERHADAP SIKAP GURU PADA PENDIDIKAN INKLUSIF
}

\author{
Tita Tri Utami Dewi ${ }^{1}$, Sri Tiatri $^{2}$, Heni Mularsih $^{3}$ \\ ${ }^{1}$ Program Studi Magister Psikologi, Universitas Tarumanagara, Jakarta \\ Email: tita.707179203@fpsi.untar.ac.id \\ ${ }^{2}$ Fakultas Psikologi, Universitas Tarumanagara, Jakarta \\ Email: sri.tiatri@untar.ac.id \\ ${ }^{3}$ Fakultas Psikologi, Universitas Tarumanagara, Jakarta \\ Email:henim@mku.untar.ac.id
}

Masuk : 08-02-2020, revisi: 29-10-2020, diterima untuk diterbitkan : 29-10-2020

\begin{abstract}
In inclusive education, children with special needs $(A B K)$ should get educational services together with normal children. However, inclusive education services that occur in Indonesia are still experiencing obstacles. Previous research has found that the problems are the lack of knowledge of teachers about children with special needs, the lack of teacher skills in dealing with children with special needs, and teachers' attitudes towards children with special needs. Current research intended to analyse the attitude of inclusive education teachers. The measurement of knowledge is developed by researchers using prior knowledge theory. In measuring teacher efficacy, we use the Teacher Efficacy for Inclusive Practices (TEIP) measurement. Teacher attitudes towards inclusive education was measured by the Multidimensional Attitudes Toward Inclusive Education Scale (MATIES). The participants were 60 teachers from state primary school, and incusive private primary school in Bogor Regency. Participants were recruited by convenience sampling technique. The research method uses correlational quantitative methods. The results showed that the knowledge and efficacy of teachers together did not provide a significant contribution to the attitude of teachers in inclusive education. Partially, knowledge about children with special needs has no effect on teachers' attitudes on inclusive education. However, independently, only teacher efficacy contributed significantly to teachers' attitudes regarding inclusive education.
\end{abstract}

Keywords: prior knowledge, teacher efficacy, attitude, inclusive education

\begin{abstract}
ABSTRAK
Dalam pendidikan inklusi, seharusnya anak berkebutuhan khusus (ABK) mendapatkan pelayanan pendidikan bersama dengan anak yang normal. Namun, pelayanan pendidikan inklusif yang terjadi di Indonesia masih mengalami hambatan. Penelitian terdahulu menemukan bahwa hambatan yang terjadi selama ini adalah kurangnya pengetahuan guru tentang anak berkebutuhan khusus, minimnya keterampilan guru dalam menangani $A B K$, dan sikap guru terhadap ABK yang dilihat masih memandang sebelah mata. Penelitian ini bertujuan untuk mengetahui peran pengetahuan awal tentang $\mathrm{ABK}$ dan efikasi guru terhadap sikap guru pendidikan inklusif. Pengukuran pengetahuan dikembangkan oleh peneliti dengan menggunakan teori prior knowledge. Untuk pengukuran efikasi guru, digunakan alat ukur The Teacher Efficacy for Inclusive Practices (TEIP). Pengukuran sikap guru terhadap pendidikan inklusif menggunakan alat ukur The Multidimensional attitudes toward inclusive education scale (MATIES). Partisipan berjumlah 60 guru dari SDN dan SD Swasta Inklusi di Kabupaten Bogor, yang terpilih dengan teknik sampling convenience. Metode penelitian menggunakan metode kuantitatif korelasional. Hasil penelitian menunjukkan bahwa pengetahuan dan efikasi guru secara bersama-sama tidak memberikan sumbangan yang signifikan terhadap sikap guru pendidikan inklusif. Secara parsial, pengetahuan mengenai anak berkebutuhan khusus tidak memberikan pengaruh terhadap sikap guru pada pendidikan inklusi. Namun secara independen hanya efikasi guru yang memberikan sumbangan yang signifikan terhadap sikap guru mengenai pendidikan inklusif.
\end{abstract}

Kata Kunci: pengetahuan awal, efikasi guru, sikap guru terhadap pendidikan inklusif

\section{PENDAHULUAN}

\section{Latar Belakang}

Berdasarkan UU No. 20 tahun 2003 Pasal 32 ayat 1, pendidikan khusus merupakan pendidikan bagi peserta didik yang memiliki tingkat kesulitan dalam mengikuti proses pembelajaran karena 
kelainan fisik, emosional, mental, sosial dan / atau memiliki potensi kecerdasan dan bakat istimewa. Pada ayat 2 pendidikan layanan khusus merupakan pendidikan bagi peserta didik di daerah terpencil atau keterbelakang, masyarakat adat yang terpencil, dan / atau yang mengalami bencana alam, bencana sosial dan tidak mampu dari segi ekonomi (Dirjen Manajemen Dikdasmen 2006, dalam Mangunsong, 2014). Tujuan sekolah inklusif adalah menekankan keterlibatan siswa berkebutuhan khusus ke dalam kehidupan sekolah secara menyeluruh (Smith, 2014). Hal yang mendasar dalam pendidikan inklusi adalah tentang memiliki, memelihara dan mendidik semua siswa tanpa mempedulikan perbedaan mereka dalam kemampuan, budaya, jenis kelamin, bahasa, kelas dan etnisitas (Kozleski, et.al., dalam Savolainen, Engelbrechtb, Nel, \& Malinen, 2011).

Baska dan Stambaugh (dalam Juwono \& Kumara, 2011) menyatakan bahwa pelayanan pendidikan inklusif yang terjadi di Indonesia masih mengalami hambatan, hambatan yang terjadi selama ini adalah kurangnya pengetahuan guru tentang anak berkebutuhan khusus, minimnya keterampilan guru dalam menangani $\mathrm{ABK}$ dan sikap guru terhadap $\mathrm{ABK}$ yang dilihat masih memandang sebelah mata. Berdasarkan hasil penelitian Sunardi, Yusuf, Gunarhadi, Priyono, dan Yeager (2011) ditemukan bahwa masih banyak sekolah inklusif di Indonesia yang hanya sedikit atau hampir tidak melakukan perubahan sama sekali untuk mengakomodir program sekolah inklusif. Salah satu evaluasinya adalah guru pendidikan umum dirasakan tidak membedakan strategi pengajaran bagi anak berkebutuhan khusus dengan anak-anak lainnya (Kurniawati, De Boer, Minnaert, \& Mangunsong, 2017; Mangunsong, 2014).

Guru merupakan pendidik yang memiliki peranan penting dalam pelaksanaan pendidikan inklusif (Forlin, et.al., dalam Kumar \& Midha, 2017). Keberhasilan pendidik dalam ruang lingkup pendidikan inklusif menjadi tantangan yang besar. Banyak tantangan yang perlu dihadapi seperti kesiapan guru inklusif, harus ada pelatihan guru dalam menangani siswa berkebutuhan khusus, kurangnya fleksibilitas kurikulum, kelas/ruang belajar yang tidak sesuai, intimidasi terhadap anak-anak berkebutuhan khusus oleh siswa reguler, dan pemberian perhatian lebih yang dilakukan oleh guru untuk anak berkebutuhan khusus guna mendorong siswa untuk lebih aktif dan terampil secara sosial (Kumar \& Midha, 2017), serta untuk memberikan pemahaman lebih mendalam terhadap materi yang diajarkan dibandingkan siswa reguler (Garguilo, 2012).

Kesiapan guru dan pihak sekolah dalam menyelenggarakan pendidikan inklusif dipengaruhi oleh sikap yang dapat memengaruhi keberhasilan pendidikan inklusif (Layser \& Tappendorf, 2001). Ajzen (2005) menyatakan bahwa sikap adalah sebuah kecenderungan (disposisi) untuk berespon senang atau tidak senang terhadap objek, orang, institusi ataupun kejadian. Adapun respon terbagi dalam tiga kategori: kognitif, afektif, dan konatif. Kategori kognitif merefleksikan persepsi dan pemikiran dari objek sikap. Berdasarkan penelitian, sikap guru adalah penentu keberhasilan yang signifikan dalam kelas inklusif dan sikap guru dapat memengaruhi perilaku, iklim kelas dan peluang siswa untuk sukses (Avramidis \& Norwich, 2002; Jordan, Schwartz, \& McGhie-Richmond, 2009). Sikap guru terhadap pendidikan inklusif didefinisikan sebagai kecenderungan untuk berespon secara kognitif, afektif, dan konatif terhadap pendidikan inklusif (Mahat, 2008). Sikap guru terhadap inklusif tersebut dapat dipengaruhi oleh beberapa faktor terkait siswa, guru, dan lingkungan pendidikan. Terkait dengan siswa, sikap guru dipengaruhi oleh jenis disabilitas yang disandang oleh siswa (Forlin, Keen, \& Barrett, 2008) sedangkan berdasarkan faktor demografis guru turut memengaruhi sikap seperti tingkat kelas yang diajar, gender, pengalaman, pelatihan, keyakinan dan pandangan sosio-politik guru. 
Sikap guru pada pendidikan inklusif dapat positif maupun negatif. Sikap positif muncul tergantung pada kemampuan, pengalaman, pelatihan, fleksibilitas yang ada dalam kurikulum dan jenis ketidakmampuan siswa, dan ukuran kelas (Kumar \& Midha, 2017). Guru yang memiliki sikap positif terhadap pendidikan inklusif dinilai lebih memiliki kepercayaan diri terhadap kemampuannya untuk memberikan dukungannya kepada siswa dan mampu mengadaptasi bahan ajar serta prosedur kelas untuk mengakomodasi kebutuhan seluruh siswanya (Campbell, Gilmore, \& Cuskelly, 2014) sedangkan guru yang memiliki sikap negatif terhadap pendidikan inklusif akan merasa tidak siap untuk menerima siswa berkebutuhan khusus dan enggan untuk menyediakan dukungan yang dibutuhkan bagi siswa tersebut (Cassady, (2011).

Selain sikap, kesuksesan program inklusif juga tergantung pada pengetahuan, keterampilan dan kompetensi yang dimiliki guru agar dapat menjadi guru yang efektif di sekolah inklusif (Winter, 2006). Pengetahuan merupakan suatu kesadaran dalam bidang kognitif. Pengetahuan pada guru inklusif ialah seperti mengetahui cara mengidentifikasikan kebutuhan belajar dan bagaimana melakukan pembelajaran terhadap siswa-siswi berkebutuhan khusus sesuai dengan kebutuhan dan fase perkembangannya. Guru yang memiliki pengetahuan dan pengalaman dalam mengajar anak berkebutuhan khusus memiliki pemahaman yang lebih baik tentang inklusi dan lebih mampu memotivasi siswa tersebut dengan lebih baik daripada rekan-rekan guru lain (Buell, Hallam, Gamel-McCormick, \& Scheer, 1999, dalam Subramanian \& Manickaraj, 2017)

Untuk mengetahui kemampuan dan kebutuhan khusus peserta didik, guru harus memiliki pengetahuan awal tentang peserta didik sebelum menyusun rencana pembelajaran yang akan dilaksanakan (Pellegrino, 2005). Pengetahuan awal yang tidak memadai atau terfragmentasi adalah masalah penting untuk dipertimbangkan karena jika ada ketidaksesuaian antara harapan instruktur terhadap pengetahuan seseorang dan basis pengetahuan aktual seseorang, pembelajaran mungkin terhambat sejak awal mula proses pembelajaran. Seorang guru yang efektif seharusnya dapat menyadari perbedaan di antara peserta didik serta memahami pengaruh dari latar belakang, kemampuan, dan kebutuhan belajar yang berbeda dalam proses pembelajaran (Wiseman et.al., dalam Rahman, Yahya, \& Jalil, 2010) sehingga guru perlu memiliki pengetahuan dasar dan juga kesadaran bahwa peserta didik di kelas memiliki karakteristik yang berbeda dalam kemampuan dan kebutuhan yang berbeda (Rahman et.al., 2010). Oleh karena itu, pemahaman pengetahuan guru reguler, sikap dan keterampilan kompetensi mereka sangat penting untuk membawa perubahan yang tepat untuk penerimaan mereka terhadap siswa yang beragam di kelas mereka dan dalam strategi pengajaran mereka (Janney, Snell, Beers \& Raynes, 1995; Bender, Vail \& Scott , 1995; Stanovich \& Jordan, 1998; Soodak, Podell \& Lehman, 1998; McLesky \& Waldron, 2002, dalam Subramanian \& Manickaraj, 2017).

Dalam penyelenggaraan pendidikan inklusif, seorang guru harus memiliki pengetahuan mengenai anak berkebutuhan khusus dan melakukan perencanaan pembelajaran yang disesuaikan dengan kebutuhan siswa-siswi dengan mengacu pada kurikulum yang disesuaikan. Guru harus dapat menyusun rencana program pembelajaran individual (PPI) dengan memodifikasi kurikulum disesuaikan pada kemampuan anak didik. Selain itu, proses pembelajaran dilaksanakan sesuai dengan kondisi dan kemampuan siswa-siswi yang menekankan pada proses belajar yang optimal. Pembelajaran dapat bersifat fleksibel dengan melihat pada kemajuan anak, penilaian meliputi pengukuran terhadap materi yang telah dipelajari dengan standar individual pada kemampuan dasar yang harus dikuasai, dan yang terakhir adalah pengawasan pembelajaran yang dilakukan tidak hanya oleh pihak sekolah namun bekerja sama dengan orang tua dan lingkungan masyarakat (Garnida, 2015). 
Selain tingkat pengetahan guru, faktor lain yang membuat pendidikan inklusi kurang berjalan dengan baik adalah kurangnya keyakinan guru dalam mengajar dalam setting inklusif. Vaz, Wilson, Falkmer, Sim, Scott, Cordler \& Falkmer (2015) menyatakan bahwa terdapat beberapa faktor yang dapat memprediksi sikap guru terhadap pendidikan inklusif, salah satunya yaitu efikasi diri dalam mengajar. Penelitian tersebut menunjukkan bahwa guru yang memiliki keyakinan atau efikasi diri yang rendah dalam mengajar, juga memiliki sikap yang lebih negatif terhadap pendidikan inklusif. Hal ini sejalan dengan penelitian yang dilakukan oleh Savolainen, Engelbrecht, Nel dan Malinen (2012) yang menyatakan bahwa semakin guru yakin akan kemampuannya dalam mengimplementasikan pendidikan inklusif, maka semakin positif sikap yang ditunjukkan guru terhadap pendidikan inklusif.

Keyakinan guru dalam mengajar sangat membantu terlaksananya pendidikan inklusi yang efektif, mengingat tantangan yang dihadapi akan lebih kompleks dibandingkan dengan pendidikan reguler. Guru dengan efikasi yang tinggi akan mendorong siswa untuk lebih baik dalam belajar melalui perencanaan kegiatan pembelajaran dan dalam berinteraksi dengan siswa, misalnya membantu siswa berkebutuhan khusus untuk tekun dalam pengerjaan tugas dan menghadapi tuntutan akademis (Schunk, Pintrich \& Meece, 2010). Sedangkan guru yang memiliki efikasi yang rendah cenderung tertekan dan marah pada perilaku buruk siswa, bersikap pesimis terhadap kemampuan siswa untuk maju dan sering memilih model pendisiplinan restruktif. Sebaliknya guru yang memiliki efikasi yang tinggi cenderung percaya diri dalam mengelola kelas (Melba, dalam Santrock, 2009). Dengan demikian efikasi guru merupakan prediktor yang sangat kuat dalam hubungannya terhadap sikap positif dalam pendidikan inklusi (Weisel \& Dror, 2006).

Penelitian-penelitian sejenis sudah dilaksanakan di luar Indonesia. Di Indonesia, sepanjang pengetahuan penulis, penelitian sejenis masih jarang dilaksanakan. Berdasarkan pemikiran di atas, maka rumusan masalah dalam penelitian ini adalah "apakah pengetahuan awal tentang anak berkebutuhan khusus dan efikasi guru berperan terhadap sikap guru pada pendiditan inklusif?"

\section{METODE PENELITIAN}

Penelitian ini dilakukan di tiga sekolah dasar yang berlokasi di kabupaten Bogor, yakni SDN X, SDN Y, dan SD Swasta. Karakteristik partisipan pada penelitian ini adalah guru yang memiliki tugas mengajar minimal 1 tahun di sekolah inklusif pada tingkat sekolah dasar di wilayah Bogor, baik sekolah negeri maupun swasta. Guru tersebut merupakan guru kelas atau guru mata pelajaran yang memiliki tugas mengajar hampir setiap hari berinteraksi dengan anak berkebutuhan khusus. Jumlah partisipan adalah 60 guruyang mengajar di sekolah $\mathrm{n}$ inklusif yang terdiri dari 19 pria dan 41 wanita yang berlatar belakang pendidikan mulai dari diploma hingga Strata 2.

Teknik pengambilan sampel menggungakan convinience sampling, yaitu pengambilan sampel didasarkan pada ketersediaan elemen dan kemudahan untuk mendapatkannya. Sampel diambil/terpilih karena sampel tersebut ada pada tempat dan waktu yang tepat. Metode penelitian ini menggunakan kuntitatif korelasional. Pengambilan data dilakukan pada tanggal 8 hingga 18 Oktober 2018 dengan menyebarkan kuesioner yang dibantu oleh masing-masing kepala sekolah dengan membagikan kepada para guru sesuai dengan karakteristik yang telah ditetapkan.

Pengumpulan data pada penelitian ini menggunakan instrumen berupa kuesioner yang terdiri dari tiga instrumen penelitian, pertama adalah Multi-dimensional Attitude toward Inclusive Education Scale (MATIES) yang dikembangkan oleh Mahat (2008) untuk mengukur sikap guru terhadap pendidikan inklusif. Instrumen MATIES diukur melalui dimensi afektif, kognitif, dan perilaku, 
kedua adalah instrumen yang mengukur pengetahuan awal guru mengenai disabilitas yang dikembangkan oleh peneliti berdasarkan International Classification of Diseases-10 (ICD-10) dari the World Health Organisation (WHO 2011) dengan fokus penelitian pada disabilitas Dyslexia, ADHD, Intellectual Disability, dan Autism Spectrum Disorder. Instrumen pengetahuan diukur berdasarkan dimensi knowledge of facts, knowledge of meaning, Integration of knowledge, application of knowledge. Instrumen ketiga adalah Teacher Efficacy for Inclusive Practice (TEIP) yang dikembangkan oleh Sharma, Loreman \& Forlin (2011) untuk mengukur efikasi guru dalam pendidikan inklusif. Instrumen TEIP diukur melalui dimensi Efficacy to Use Inclusive Instruction, Efficacy in Collaboration dan Efficacy in Managing Behaviour.

Berdasarkan hasil uji validitas menunjukkan bahwa pada alat ukur MATIES terdapat 3 item yang tidak valid dan setelah penghapusan item tersebut menghasilkan koefisien realibiltas sebesar 0,838. Pada alat ukur pengetahuan awal tentang anak berkebutuhan terdapat 17 butir yang harus dihapus karena nilainya dibawah 0,2 sehingga total item yang tersisa berjumlah 14 item dan hasil uji validitas dan realibilitas alat ukur ini adalah 0,790. Sedangkan pada alat ukur TEIP reliabilitasnya sebesar 0,866 setelah dilakukan penghapusan terhadap 3 butir item yang tidak valid.

\section{HASIL DAN PEMBAHASAN}

Penelitian ini menggunakan teknik statistik deskriptif untuk mengetahui gambaran umum variabel-variabel penelitian dengan perangkat SPSS versi 22 dalam mengolah data. Tahap pertama adalah analisis alat ukur dengan menguji reliabilitas untuk mengukur konsistensi alat ukur apakah stabil dari waktu ke waktu. Tahap berikutnya adalah uji asumsi klasik yang berfungsi untuk memberikan kepastian bahwa persamaan regresi yang didapatkan memiliki ketepatan dalam estimasi, tidak bias dan konsisten. Uji normalitas bertujuan untuk menguji apakah dalam model regresi, variabel pengganggu atau residual memiliki distribusi yang normal. Penelitian ini menggunakan Uji Kolmogorov-Smirnov (K-S) dan Analisa Grafik yaitu Normal QQ Plot. Pada Uji K-S, variabel dikatakan berdistribusi normal jika signifikansi lebih dari .05. Variabel juga dikatakan berdistribusi normal jika pada Normal Q-Q Plot, titik-titik berada di sekitar garis diagonal (Ghozali, 2017). Kemudian peneliti melakukan uji regresi berganda atau multiple regression untuk melihat seberapa besar sumbangan variabel pengetahuan awal tentang anak berkebutuhan khusus dan efikasi guru pada sikap guru terhadap pendidikan inklusif. Terakhir adalah independent sample t-test dan one way ANOVA, pengujian ini digunakan untuk melihat antara data diri partisipan yang diperoleh pada penelitian ini terhadap variabel terikat.

Pengukuran uji normalitas menunjukkan bahwa ketiga variabel berdistribusi normal. Sebaran distribusi data pengetahuan diuji dengan Uji Kolmogorov-Smirnov. Pada variabel pengetahuan tentang anak berkebutuhan khusus hasil uji yang diperoleh tidak berdistribusi normal atau signifikansi di bawah 0,5 sehingga dilakukan uji normal Q-Q Plot. Uji QQ Plot menunjukkan variabel pengetahuan berdistribusi normal yang dibuktikan dengan data tersebar di sekeliling garis diagonal. Hasil Uji Linieritas menunjukkan bahwa kedua variabel bebas (pengetahuan awan dan self efficacy) memiliki hubungan yang linier terhadap variabel terikat karena signifikansi keduanya di atas 0,05 .

Analisis deskriptif dilakukan untuk melihat penyebaran skor-skor dari suatu kelompok yang digunakan sebagai acuan untuk memberi makna pada skor individu. Pada variabel sikap, jumlah responden yang memiliki sikap positif yang tinggi sebesar $21,7 \%$, responden yang memiliki sikap positif yang sedang sebesar 53,3 \%, dan responden yang memiliki sikap positif yang rendah sebesar $15 \%$. Sedangkan responden yang memiliki pengetahuan yang tinggi mengenai 
ABK sebesar 23,3\%. Responden yang memiliki pengetahuan yang sedang mengenai ABK sebesar 53,3\%, dan responden yang memiliki pengetahuan yang rendah mengenai ABK sebesar $23,3 \%$. Untuk variabel efikasi guru, terdapat $25 \%$ yang memiliki efikasi yang tinggi terhadap pendidikan inklusi, sedangkan yang memiliki efikasi yang sedang terhadap pendidikan inklusi terdapat $32 \%$ dan responden yang memiliki efikasi yang rendah terhadap pendidikan inklusi terdapat $21,7 \%$. Berikut hasil perhitungan norma berdasarkan data dmografis.

Hasil Analisis Berdasarkan Jenis Kelamin. Sikap positif yang tinggi terhadap pendidikan inklusif lebih banyak pada guru wanita (29\%) dibandingkan guru pria (16\%). Sikap negatif terhadap pendidikan inklusif, baik guru pria dan wanita memiliki persentase yang hampir sama, yakni guru pria $21 \%$ dan guru wanita adalah $22 \%$. Guru pria lebih dominan memiliki sikap yang netral terhadap pendidikan inklusif ( $63 \%$ ).

Hasil Analisis Berdasarkan Pendidikan. Hasil menunjukkan bahwa guru dengan latar pendidikan S2 memiliki sikap positif yang tinggi terhadap pendidikan inklusif yakni sebesar $50 \%$. Guru dengan lulusan S1 umumnya memiliki sikap yang netral, yaitu 54\%, sedangkan guru dengan lulusan Diploma memiliki sikap yang negatif atau rendah terhadap pendidikan inklusif dengan persentase $50 \%$.

Hasil Analisis Berdasarkan Lama Mengajar. Hasil menunjukkan bahwa guru yang bekerja sebagai guru selama 6 smpai 10 tahun memiliki sikap yang netral paling dominan terhadap pendidikan inklusif, yaitu sebesar $80 \%$. Guru yang lama mengajarnya sekitar 1 sampai 5 tahun memiliki sikap positif terhadap pendidikan inklusif paling banyak yaitu sebesar $49 \%$, dan yang memiliki sikap negatif paling dominan adalah guru yang memiliki lama mengajar 16 hingga 20 tahun.

Hasil Analisis Berdasarkan Status Guru. Hasil menunjukkan bahwa guru yang mengajar mata pelajaran memiliki sikap yang lebih positif terhadap pendidikan inklusif (35\%) dibandingkan guru kelas (18\%). Guru kelas tampak memiliki sikap negatif lebih banyak (26\%) dibandingkan guru mata pelajaran $(15 \%)$.

Hasil Analisis Berdasarkan Pelatihan Guru. Berdasarkan tabel 1.8 guru yang pernah mengikuti pelatihan pendidikan inklusif memiliki sikap positif yang lebih banyak dibandingkan guru-guru yang tidak pernah mengikuti pelatihan. Guru-guru yang tidak pernah mengikuti pelatihan pendidikan inklusif juga tampak memiliki sikap negatif lebih banyak dibandingkan guru-guru yang pernah mengikuti pelatihan pendidikan inklusif.

Hasil Analisis Berdasarkan Status Sekolah. Hasil menunjukkan bahwa sekolah negeri tidak memiliki sikap positif yang tinggi terhadap pendidikan inklusif, tetapi sikap mereka lebih dominan netral $(55 \%)$ dan rendah (45\%). Begitupula pada sekolah swasta yang dominan memiliki sikap netral terhadap pendidikan inklusif (55\%), tetapi masih ada guru yang memiliki sikap positif terhadap pendidikan inklusif sebesar $31 \%$.

Berdasarkan uji hipotesis, dihasilkan nilai koefisien determinasi pengetahuan awal tentang ABK terhadap sikap guru pada pendidikan inklusi sebesar 1,632 dengan tingkat signifikansi 0,208 atau di atas 0,05 menunjukkan bahwa tidak terdapat pengaruh pengetahuan awal tentang ABK terhadap sikap guru pada pendidikan inklusi sehingga model regresi tidak dapat digunakan untuk memprediksi variabel sikap. 
Hasil uji pada ANAVA variabel efikasi guru terhadap pendidikan inklusif dihasilkan nilai $\mathrm{F}$ sebesar 5,237 dengan tingkat signifikansi 0,027 atau dibawah 0,05. Hal ini menunjukkan bahwa terdapat pengaruh efikasi guru terhadap sikap guru pada pendidikan inklusi sehingga model regresi dapat digunakan untuk memprediksi variabel sikap.

Uji hipotesis dengan ANAVA pada ketiga variabel menghasilkan nilai $\mathrm{F}$ hitung sebesar 2,773 dengan tingkat signifikansi 0,073 atau diatas 0,05 sehingga hal ini menunjukkan secara bersamasama tidak terdapat pengaruh antara variabel pengetahuan awal tentang ABK dan efikasi guru, terhadap sikap guru pada pendidikan inklusif.

\section{Pembahasan}

Hipotesis dalam penelitian ini ditolak atau tidak teruji secara empiris. Hasil penelitian ini menunjukkan bahwa pengetahuan awal tentang anak berkebutuhan khusus dan efikasi guru secara bersama-sama tidak memberikan sumbangan yang signifikan pada sikap guru terhadap pendidikan inklusif. Begitu pula dengan variabel pengetahuan yang secara independen tidak memiliki peran yang signifikan terhadap sikap guru pada pendidikan inklusif. Hal ini sejalan dengan penelitian yang dilakukan oleh Subramanian dan Manickaraj (dalam Thomas \& Gljo, 2020) bahwa tidak ada korelasi yang ditemukan antara pengetahuan tentang anak-anak berkebutuhan khusus, efikasi guru dan sikap guru terhadap pendidikan inklusif.

Berdasarkan hasil penelitian tingkat pengetahuan responden paling banyak ada pada kategori sedang. Pengetahuan ini dapat bersifat faktual atau prosedural. Pengetahuan faktual dianggap mirip dengan pengetahuan obyektif yang mencakup karakteristik disabilitas sedangkan pengetahuan prosedural menyangkut prosedur dan keterampilan yang mencakup metode pengajaran yang menguntungkan seluruh kelas. Hasilnya menunjukkan bahwa guru memiliki lebih banyak pengetahuan prosedural tentang disabilitas dibandingkan mengetahui jenis disabilitas.

Selain data statistik, peneliti juga melakukan wawancara kepada dua guru yang setiap hari berinteraksi dengan siswa berkebutuhan khusus. Mereka berpendapat bahwa meskipun tingkat pengetahuannya rendah mengenai pendidikan inklusif dan anak berkebutuhan khusus, mereka memiliki sikap yang positif kepada siswa-siswanya yang berkebutuhan khusus. Mereka berpendapat meskipun terkadang kesal saat mengajar siswa berkebutuhan khusus, namun anakanak tersebut berhak mendapatkan pengajaran yang sesuai dengan kebutuhannya. Dengan begitu, para guru membutuhkan lebih banyak pelatihan tentang praktik-praktik inklusif, tidak hanya memusatkan pengetahuan mereka, tetapi juga keterampilan dan pengalaman mereka dan penting adanya pelatihan secara langsung untuk bekerja dengan anak-anak berkebutuhan khusus (CraneMitchel \& Hedge, 2007).

Berdasarkan hasil penelitian Sadler (2005) mengenai efikasi diri, sikap, dan pengetahuan guru tentang inklusi adalah banyak guru memperoleh pengetahuan tentang anak-anak melalui pengalaman dan buku. Hal ini langsung menyiratkan bahwa mereka tahu bagaimana menggunakan pengetahuan tersebut di kelas inklusif. Sehingga peneliti berasumsi bahwa bagi beberapa guru meskipun tidak mengikuti pelatihan, namun pengetahuannya akan bertambah dengan membaca literatur mengenai pendidikan inklusi. Selain itu, pengalaman (lama mengajar) dapat memengaruhi pengetahuan seorang guru. 
Meskipun pengetahuan tidak memiliki peran dalam penelitian ini, tetapi berdasarkan hasil penelitian, efikasi guru dapat memengaruhi sikap guru terhadap pendidikan inklusi. Efikasi guru yang tinggi akan mendorong siswa untuk lebih baik dalam belajar melalui perencanaan kegiatan pembelajaran dan dalam berinteraksi dengan siswa, misalnya membantu siswa untuk tekun dalam pengerjaan tugas dan menghadapi tuntutan akademis (Schunk, Pintrich \& Meece, 2010), sehingga efikasi guru merupakan prediktor yang sangat kuat dalam hubungannya terhadap sikap positif dalam pendidikan inklusi (Weisel dan Dror, 2006).

Berdasarkan uji norma, sikap positif yang tinggi terhadap pendidikan inklusif lebih banyak pada guru wanita dibandingkan guru pria. Hal ini sejalan dengan hasil penelitian yang dilakukan oleh Avramidis, Bayliss, dan Burden (2000) Avramidis \& Norwich (2002) serta penelitian yang dilakukan oleh Vaz, Wilson, Falkmer, Sim, Scott, Cordier, dan Falkmer (2015). Hasil dari penelitian ini menunjukkan bahwa gender tampaknya menjadi prediktor sikap guru terhadap inklusi dan bahwa guru pria cenderung memiliki sikap yang lebih negatif daripada guru wanita.

Latar belakang pendidikan juga dapat memengaruhi sikap guru pada pendidikan inklusif. Guru yang berlatang belakang pendidikan S2 memiliki sikap positif yang lebih baik dibandingkan guru berlatar belakang S1 dan diploma. Dalam penelitian ini, subjek yang berlatar belakang S2 hanya 1 orang dan sisanya 13 orang berpendidikan S1 (sikap netral terhadap Pendidikan inklusi).Hal ini yang diduga sebagai penyebab hipotesis tidak teruji

Pegalaman mengajar adalah salah satu faktor yang dapat memengaruhi sikap guru terhadap pendidikan inklusif. Pada penelitian ini, guru yang memiliki pengalaman mengajar 1 hingga 5 tahun memiliki sikap positif yang tinggi terhadap pendidikan inklusif. Hal ini sejalan dengan penelitian Savolainen, Engelbrecht, Nel, dan Malinen (2011), Todorovic, Stojiljkovic, dan Djigic (2011) dan Dukmak (2013) yang mengungkapkan bahwa guru dengan pengalaman inklusif.

Status atau kedudukan guru di sekolah juga dapat memengaruhi sikap guru pada pendidikan inklusi. Hasil penelitian ini menunjukkan bahwa guru mata pelajaran memiliki sikap yang lebih positif dibandingkan guru kelas. Berdasarkan penelitian Humphrey dan Symes (dalam Sharma \& Sokal, 2016) menyatakan bahwa administrator dan koordinator untuk inklusi memiliki sikap yang lebih positif terhadap inklusi daripada guru kelas. Sedangkan guru kelas memiliki sikap paling negatif tentang anak-anak yang memiliki kebutuhan khusus (Sharma \& Sokal, 2016).

Berdasarkan hasil penelitian, status sekolah juga dapat memengaruhi sikap guru terhadap pendidikan inklusif. Guru-guru yang berasal dari sekolah negeri maupun swasta cenderung memiliki sikap yang netral terhadap pendidikan inklusif. Akan tetapi, pada sekolah swasta masih ada guru yang memiliki sikap positif terhadap pendidikan inklusif meskipun tidak banyak. Sedangkan di sekolah negeri tidak ada yang menunjukkan sikap yang positif terhadap pendidikan inklusif. Berdasarkan penelitian Mc Kinnon, Lydia, dan Jase (2013) guru pada sekolah dasar swasta memiliki tingkat kesenangan mengajar yang lebih tinggi dibandingkan sekolah negeri. Sekolah dasar negeri fokus pada kemajuan kemampuan dan strategi mengajar guru, sedangkan guru pada sekolah dasar swasta lebih mampu untuk mengeluarkan strategi pengajaran yang sesuai dengan kebutuhan siswa serta tenaga profesional untuk mengajarkan kedisiplinan pada siswa.

Pelatihan mengenai pendidikan inklusif pada guru-guru juga merupakan faktor yang dapat memengaruhi sikap pada pendidikan inklusif. Hasil penelitian ini adalah guru yang pernah mengikuti pelatihan pendidikan inklusif memiliki sikap positif yang tinggi dibandingkan guru- 
guru yang tidak pernah mengikuti pelatihan. Guru-guru yang tidak pernah mengikuti pelatihan pendidikan inklusif juga tampak memiliki sikap negatif lebih banyak dibandingkan guru-guru yang pernah mengikuti pelatihan pendidikan inklusif. Subban dan Sharma (2006) melaporkan bahwa guru yang pernah mengikuti pelatihan tentang mengajar peserta didik berkebutuhan khusus memiliki sikap yang lebih positif dibandingkan guru yang tidak mengikuti pelatihan. Demikian juga Kurniawati, et al (2012) melaporkan bahwa guru yang pernah mengikuti pelatihan pendidikan khusus memiliki skor yang lebih tinggi pada komponen kognitif-afektif dan komponen perilaku. Kurniawati, et al (2017) juga menemukan bahwa setelah diberikan pelatihan, guru-guru sekolah dasar memiliki sikap yang lebih positif terhadap pendidikan inklusif dibandingkan guru yang tidak diberikan pelatihan.

\section{SIMPULAN DAN SARAN}

Berdasarkan hasil uji hipotesis, dapat disimpulkan bahwa pengetahuan dan efikasi guru secara bersama-sama tidak memberikan sumbangan yang signifikan pada sikap guru terhadap pendidikan inklusif sehingga hipotesis ditolak atau tidak teruji secara empiris (sig. 0,073>0,05). Selain itu, tidak ada pengaruh pengetahuan yang signifikan pada sikap guru terhadap pendidikan inklusif (sig. 0,208 > 0,05). Namun, efikasi diri secara independen memberikan pengaruh yang signifikan pada sikap guru terhadap pendidikan inklusif (sig. 0,027<0,05).

Peneliti selanjutnya diharapkan menggunakan variabel yang lebih bervariatif berkenaan dengan pendidikan inklusif karena belum ditemukan penelitian-penelitian mengenai pendidikan inklusif di Indonesia yang lebih beragam. Selain itu, dalam pelaksanaan penelitian sebaiknya pengisian kuesioner didampingi oleh peneliti seperti menyatukan partisipan dalam satu ruangan dan diawasi oleh peneliti. Dengan begitu, peneliti dapat membuat janji sebelumnya agar pihak sekolah mau meluangkan waktu untuk pengambilan data. Hal ini karena kesibukan atau menunda-nunda pengisian kuesioner menjadi alasan utama ketidaksediaan sekolah untuk mengisi langsung kuesioner saat kuesioner diserahkan kepada peneliti.

Selain itu, ada baiknya pendekatan kualitatif (wawancara) digunakan untuk melengkapi data kuantitatif yang diperoleh. Penelitian selanjutnya dapat mengeksplorasi pandangan dan kesan guru kelas terhadap pendidikan inklusif melalui wawancara sehingga dapat dijadikan perbandingan dengan data kuantitatif yang diperoleh. Hal ini disebabkan adanya kemungkinan data kuesioner atau kuantitatif yang tidak jujur, sehingga hasilnya tidak menggambarkan jawabannya yang sebenarnya.

\section{Ucapan Terima Kasih (Acknowledgement)}

Peneliti mengucapkan terima kasih kepada para guru di SD Inklusi Negeri dan Swasta yang telah bersedia untuk berpartisipasi dalam seluruh proses dalam penelitian ini. Terima kasih kepada Kepala Sekolah yang telah mengizinkan pengambilan data di sekolah-sekolah yang dipimpin.

\section{REFERENSI}

Ajzen, I. (2005). Attitude, personality and behavior (2 ${ }^{\text {nd }}$ ed). New York: McGraw Hill.

Avramidis, E., Bayliss, P., \& Burden, R. (2000). Student teachers' attitudes toward the inclusion of children with special education needs in the ordinary school. Teaching and

Teacher Education, 20, 191-211. DOI: 10.1080/713663717.

Avramidis, E., \& Norwich, B. (2002) Teachers' attitudes towards integration / inclusion: a review of the literature. European Journal of Special Needs Education, 17(2), 129-147. https://doi.org/10.1080/08856250210129056 
Campbell, J., Gilmore, L., \& Cuskelly, M. (2014). Changing Student Teachers Attitudes Towards Disability and Inclusion. Journal of Intellectual and Developmental Disability, 28 (4), 369-379. https://doi.org/10.1080/13668250310001616407

Cassady, J. M. (2011). Teachers' attitudes toward the inclusion of students with autism and emotional behavioral disorder. Electronic Journal for Inclusive Education, 2 (7). https://corescholar.libraries.wright.edu/ejie/vol2/iss 7/5/

Crane-Mitchell, L., \& Hedge, A. V. (2007). Beliefs and practices of in-service preschool teachers in inclusive settings: implications for personnel preparation. Journal of Early Childhood Teacher Education, 28, 353-366. DOI: 10.1080/10901020701686617.

Forlin, C., Keen, M., \& Barrett, E. (2008). The concerns of mainstream teachers: Coping with inclusivity in an Australian context. International Journal of Disability, Development and Education, 55(3), 251-264. https://doi.org/10.1080/13603110701365356.

Forlin, C., Loreman, T. Sharma, U., \& Earle, C. (2009). Demographic differences in changing pre-service teachers' attitudes, sentiments and concerns about inclusive education. International Journal of Inclusive Education, 13, 195-209

Garnida, D. (2015). Pengantar pendidikan inklusif. Bandung: Refika

Jordan, A., Schwartz, E., \& McGhie-Richmond, D. (2009). Preparing teachers for inclusive classrooms. Teaching and Teacher Education, 25(4), 535-542. https//doi.org/10.1016/j.tate.2009.02.010

Juwono, I. D \& Kumara, A. (2011). Pelatihan Penyusunan Rancangan Pembelajaran pada Guru Sekolah Inklusi. Studi Kasus Pada SD "X” di Yogyakarta. Diambil tanggal 22 September 2018, dari http://repository.gunadarma.ac.id/941/1/ PELATIHAN\%20 PENYUSUNAN\%20RANCANGAN\%20PEMBELAJARAN_UG.pdf

Kementerian Pendidikan Nasional. (2003). Undang-undang No. 20/2003 tentang system pendidikan nasional. Jakarta: Kementrian Pendidikan Nasional

Kumar A, Midha P. (2017). Attitudes toward Inclusive Education among School Teachers: A Comparative Study, International Journal of Indian Psychology, 4(95). https://doi.org/18.01.166/20170402

Kurniawati, F., Minnaert, A., Mangunsong, F., \& Ahmed, W. (2012). Empirical Study on Primary School Teachers' Attitudes Towards Inclusive Education in Jakarta, Indonesia. Procedia - Social and Behavioral Sciences, 69, 1430-1436 10.1016/j.sbspro.2012.12.082

Kurniawati, F., Boer, A., Minnaert, A., Mangunsong, F. (2017). Evaluating the Effect of a Teacher Training Programme on the Primary Teachers' Attitudes, Knowledge and Teaching Strategies Regarding Special Educational Needs. Educational Psychology, 37, 287-297. https://doi.org/10.1080/01443410.2016.1176125

Layser, Y \& Tappendorf, K. (2001). Are attitudes and practices regarding mainstreaming changing? A case of two teachers in two rural school districts' Education. Education

Journal, 121(4), 751-761. https://www.sematicscholar.org./paper/Are-Attitudes-and-

Practices regarding-Mainstreaming-LeyserTappendorf/17a557e423506ad4bda6492725 40edbb17a192c5

Mahat, M. (2008). The Development Of A Psychometrically-Sound Instrument To Measure Theacher's Multidimensional Attitudes Toward Inclusive Education. International Journal Of Special Education, https://www.researchgate.net/publication/289176114_The_development_of_a_psychometrical lysound_instrument_to_measure_teachers'_multidimensional_attitudes_toward_inclusive_edu cation

Mangunsong, F. (2014). Psikologi dan pendidikan anak berkebutuhan khusus (jilid 1). Depok: LPSP3 UI. 
Pellegrino, J. W. (2005). The Challenge of Knowing What Students Know. Measurement: Interdisciplinary Research and Perspectives. Diambil dari https://www.researchgate.net /profile/James_Pellegrino/publication/237215110_The_Challenge_of_Knowing_What_S tudents_Know/links/5404c3620cf23d9765a6c3d3/The-Challenge-of-Knowing-WhatStudents-Know.pdf?origin=publication_detail.

Rahman, A. F., Scaife, A., Yahya, N. A., \& Jalil, A. H. (2010). Knowledge of Diverse Learners: Implications for the Practice of Teaching. International Journal of Instruction, 3(2), 8396. https://files.eric.ed.gov/fulltext/ED522935.pdf.

Savolainen, H., Engelbrecht, P., Nel, M., Malinen, O-P. (2012). Understanding teachers' attitudes and self-efficacy in inclusive education: Implications for pre-service and in-service teacher education. European Journal of Special Needs Education, 27, 51-68. https://doi.org/10.1080/ 08856257.2011.613603

Santrock, J.W. (2009). Psikologi pendidikan ( $3^{\text {th }}$ ed). Jakarta: Salemba Humanika.

Savolainen, H., Engelbrecht, P., Nel, M., \& Malinen, O. P. (2012). Understanding teachers' attitudes and self-efficacy in inclusive education: Implications for pre-service and inservice teacher education. European Journal of Special Needs Education, 27, 51-68. doi:10.1080/08856257.2011.613603.

Sharma, U., Loreman, T., \& Forlin, C. (2011). Measuring Teacher Efficacy to Implement Inclusive Practices. Journal of Research in Special Education Needs, 2, 1-10. https://doi.org/10.1111/j.1471-3802.2011.01200

Schunk, D. H., Pintrich, P. R., \& Meece, J. L. (2010). Motivation in education: Theory, research and applications. New Jersey: Pearson

Smith, J. D. (2014). Inklusi: Sekolah ramah untuk semua. (Baihaqi, Trans). Bandung: Nuansa.

Sunardi, Yusuf, M., Gunarhadi, Priyono, \& Yeager, J. L. (2011). The Implementation of Inclusive Education for Students with Special Needs in Indonesia. Excellence in Higher Education, 2, 1-10. https://doi.org/10.5195/ehe.2011.27

Thomas, L. \& Eljo, J. G. (2020). Exploring the knowledge andattitude of primary school teachers on inclusive education. Mukt Shabd Journal, 9 (5), May. http://shabdbooks.com/gallery/221-may2020.pdf

Weisel, A., \& Dror, O. (2006). School climate, sense of efficacy and Israeli teachers' attitudes toward inclusion of students with special needs. Education, Citizenship and Social Justice, 1(2), 157-174. DOI: 10.1177/1746197906064677

Winter, E.C. (2006). Preparing new teachers for inclusive schools and classrooms. Support for Learning, 21(2), 85-91. https://doi.org/10.1111/j.1467-9604.2006.00409.x 